SZÖRÉNYI LÁSZLÓ

\title{
Johannes Campanus cseh neolatin költő és a magyar történelem ${ }^{1}$
}

Régóta tudjuk, hogy Zrínyi Miklós, "Sziget Hektora” nem csupán a magyar nemzet történelmi és irodalmi emlékezetében él, hanem része szinte az összes közép-kelet-európai nemzet, illetve ország hagyományának. Mivel a szigeti hős második felesége egy cseh grófnő volt, Eva z Rožmberka, azaz németesen-magyarosan Rosenberg Éva - a menyasszony családjának ősi várában, a dél-csehországi Jindřichův Hradecben (Nova Domus, Neuhaus) egy márványtábla is őrzi ennek a lakodalomnak az emlékét -, ezért házasságával Zrínyi Miklós cseh honosságot is nyert, amelyet természetesen fiai - az első házasságából származó György, a költő Zrínyi nagyapja, illetve a második házasságból származó kisfia, János is, aki azután Csehországban élt és ott is halt meg 1612-ben - és azok leszármazottai is örököltek. Így tehát nem csoda, hogy az egyik legtermékenyebb későhumanista csehországi latin költő, Johannes Vodnianus Campanus (Jan Kampánus Vodňanský) (1572-1622) egy fiatalkori költeményciklusában a sok törökverő magyar mellett nemcsak a szigeti hős, hanem a szintén törökverő daliává érett idősebb fia, a horvát, magyar és cseh arisztokrataként egyaránt számba vehető Zrínyi György, a költő nagyapjának (1549-1603) emlékét is megörökíti. ${ }^{2}$

A könyvecske végiglapozása nagyon tanulságos, mert igen nagy részben tartalmaz a magyar történelemre és a magyar-török harcok hő-

\footnotetext{
${ }^{1}$ A publikáció az MTA-SZTE Antikvitás és Reneszánsz: Források és Recepció Kutatócsoport (TK2016-126) támogatásával jelent meg.

2 A szigeti hős életrajzáról vö. VARGA (2016); második házasságáról UO. (174-176); a csehországi esküvőről ld. WAGNER (1877: 162-166); továbbá „SZERÉMI” (1877: 451-453).
} 
seire vonatkozó utalásokat is, amelyeket eddig a szakirodalom nem vett figyelembe. Érdemes tehát röviden áttekintenünk ebből a szempontból is. A latin könyvecske címe Turcicorum tyrannorum qui inde usque ab Otomanno rebus Turcicis praefuerunt, descriptio [...] Ubi res ipsorum gestae, historico ordine, additis in altera ubique annis breviter exponontur, magyar fordításban: „Azon török zsarnokok leírása, akik kezdve Oszmántól egészen mostanáig, a török állam élén álltak [...] Ebben röviden elmagyaráztatnak cselekedeteik, mégpedig történeti rendben, dátum szerint." A könyv Prágában jelent meg, Otthmar-féle betűkkel 1597-ben. ${ }^{3}$

A költő eredeti cseh családi neve Kumpán volt, ezt latinosította azután Campanusra. Két évvel azután, hogy ezt a török tárgyú költeményét írta, vagyis 1599-ben a prágai egyetemen megszerezte a doktori címet is. Főleg latinul írt, de emellett görögül, csehül és németül is. Nemcsak költő volt, hanem zeneszerző is; utraquista hite miatt a vesztes fehérhegyi csata után a jezsuiták hajszát indítottak ellene, és ezért kényszerüségből katolizált, majd nemsokára meghalt. ${ }^{4}$ Költészete, benne ez a török császáréletrajz-gyűjtemény egész Európában kedvező fogadtatásra talált, különösen a mű második része, amelyben nem egyszerü eseménytörténetet olvashatunk, hanem a hajdani szultánok - kezdve az elsőtől egészen az éppen akkor uralkodó III. Mohamedig - maguk szólalnak meg, mintegy sírfeliratszerü önjellemzésben foglalják össze cselekedeteiket. (Ez utóbbi igen szórakoztató is lehet: például akad olyan szultán is, II. Szelim, aki azzal dicsekszik, hogy soha életében sem a háború, sem az államügyek nem érdekelték, és kizárólag Venus gyönyöreinek hódolt.)

A törökök európai jelenléte és hódításai, valamint maga a török fenyegetés természetesen hatalmas irodalmi reakciót eredményezett, és ezen röpiratoknak vagy könyveknek a nyelve is a legtöbbször eleinte a

\footnotetext{
3 Pontos leírását, a ritka könyv lelőhelyeit és a tartalom rövid jellemzését ld. Enchiridion (1966: 256-257) - én magam az ebben a listában is szereplő brnói példányt használtam, de azóta szerencsére föltették az internetre is:

https://www2.uni-mannheim.de/mateo/camena/campanus1/te01.html.

${ }^{4}$ Életrajzát és müveinek rövid méltatását ld. HEMELÍk (2012) - a könyv végén függelék található, amely néhány darabot ebből a korai kötetből is közöl latinul és cseh fordításban. - Az utraquisták Fehérhegy utáni sorsáról vö. PAPP (2018).
} 
latin volt. ${ }^{5}$ Külön színt képvisel a sokak által forrásként használt szöveggyüjtemény, amelyet Johannes Leunclavius (Löwenklau) (1541-1594) állított össze, illetve fordított arab, török és perzsa nyelvű forrásokból, és amelyet nagy haszonnal forgatott többek között Zrínyi Miklós is. ${ }^{6}$

Campanus könyvének müfaja, tehát a török vagy más uralkodók genealogikus listája, amelyben vagy róluk szól az író, illetve összeállító, vagy ők maguk szólalnak meg versben vagy prózában, önjellemzésként vagy ön-sírfeliratként, meglehetősen divatos volt a korban. Legalaposabban a müfaj történetével Marc Laureys bonni neolatinista foglalkozott, aki végső soron a pápalistákra és pápaéletrajz-sorozatokra, illetve az ezeket utánzó, a legkülönbözőbb dinasztiák által szerkesztett és soksok fiktív elemeket is tartalmazó királygenealógiákra vezeti vissza mint mintaképekre, amelyekben az egyes királyok vagy hercegek próbálták a saját dinasztiájuk dicsőségét kiemelendő a maguk családjának valódi vagy vélt őseire alkalmazni a máshonnan összeszedett toposzokat, származtak légyen azok akár a hagiográfiából vagy az ókori történelemből. A könyvnyomtatás korától kezdve a legtöbb ilyen dinasztiagenealógia latinul jelenik meg, de vannak nemzeti nyelvü változatok is. Laureys egy dél-németalföldi neolatin költő, Philippus Meyerus a török szultánokról szóló verses portrésorozatát elemzi, amely csak annyiban különbözik - már ami magát a sorozatba való beillesztést illeti - Campanusétól, hogy ő megteszi, nyilván kalifaságuk miatt, az egész társulat, tehát az oszmán szultánok ősének magát a prófétát, Mohamedet. ${ }^{7}$ Feltét-

5 Vö. GUTHMÜLLER-KÜHLMANN (2000). A tanulmánykötetből különösen tanulságos számunkra két értekezés: WIEGAND (2000: 177-192), ill. JANKOVICS (2000: 267-274).

${ }^{6}$ KLANICZAY (1991: 181; 313; 376).

7 LAureys (2010). Philippus Meyerus könyve (Mahometi Arabis Pseudoprophetae vita versibus expressa, una cum omnibus Otomannis Turcarum Imperatoribus...) szintén elérhetö az interneten: https://play.google.com/books/reader?id=ZWNjAAAAcAAJ. Mivel Laureys maga érthető módon nem gyüjtötte ki az egyes közép- vagy kelet-európai keresztény nemzetekre vonatkozó adatokat, ezért itt csak felsorolásszerűen megemlítem, hogy milyen magyar vonatkozásokat találhatunk Meyerus művében: Szerbia meghódítását, a rigómezei csatát, Lázár fejedelem és Murád szultán halálát 1350-nél (40.); I. Bajazidról ugyanitt megtudhatjuk, hogy 1373-ban már Magyarországra is betört fosztogatni; Zsigmond királlyal az 1398. év körüli háborúk leírásánál találkozhatunk İsa Çelebinél (42.); I. Mehmet az első, aki 1405 után leigázza Oláhországot és Macedóniát, valamint észak felé túllépve a Dunán megtámadja Magyarországot is (42.); a II. Mu- 
lenül megérdemli e mü a további vizsgálatot, úgy is mint Campanus művének valószínűleg nemcsak előfutára, hanem mintája is. Ezt azonban csupán az egyes szultánokra vonatkozó adatok részletes összevetésével lehetne bizonyítani vagy cáfolni. Jelenleg ennél könnyebb feladatra vállalkozom, vagyis Campanus müvének bőséges magyar vonatkozásainak összegyüjtésére. ${ }^{8}$

1374 után, vagyis I. Bajazid szultán életrajzában fordul elő először a magyar történelmet érintő háború, vagyis a Szerbia elleni török támadás, majd legendássá lett Márk szerb királyfi, azaz Kraljevics Márkó említése után, az 1377. évnél már megtaláljuk az erdélyieket és Zsigmond császárt, akik ellenállnak a töröknek.

\section{[I. A nikápolyi csata és előzményei.]}

Parte alia Daci arma movent, his Caesaris alae

Sigsmundi [sic!] adglomerant, que postquam numinis iram 1377.

Supplicibus superant votis, densa agmina fundunt

Turcarum, contra Thrax irritatus in arma

Deposcit fortes Dacos, fortesque Croatas,

1383.

rádnak szentelt fejezetben olvashatjuk Hunyadi János hosszas magasztalását mint aki a legkiválóbb és legvitézebb hadvezér volt, valamint Ulászló várnai halálát (43.); II. Mehmetnél olvashatunk arról, Hunyadi hogyan verte vissza a szultánt - aki egyébként nem hitt sem Allahban, sem Jehovában - Nándorfehérvár falai alól (44.); II. Bajazidnál olvashatunk az általa leigázott magyar várakról (45-46.); majd jön II. (Nagy) Szulimán, ahol hosszan olvashatunk Nándorfehérvár bevételéről, majd a végzetes mohácsi csatáról, Lajos haláláról, majd a szultán budai bevonulásáról (48.); az uralkodó Szigetvár alatt bekövetkezett haláláról (51.). A költemény írása idején uralkodó III. Muráddal kapcsolatban pedig bőségesen olvashatunk a szerző által 1591-től számítható tizenöt éves háború első szakaszáról, legelsősorban az elhíresedett sziszeki ostromról és hadicselről, valamint Székesfehérvár visszavételéről 1693-ban (56-57.)

8 Szeretném megjegyezni, hogy a Campanus müvében ugyancsak bőséges számban található, Bulgáriát illető epizódokat a hazai, azaz bolgár tudományosság már összegyüjtötte, vö. Александър Николов, Трактатьт „За произхода на турските тирани” от Йоханес Воднянус Кампанус (Ян Воднянски) (1597 г.) и османското завоевание на Византия и Балканите: https://www.academia.edu/4388553/Johannes_Campanus_Vodnianus;

illetve ennek szerzői helyesbítését: Авторска справка за приносите в трудовете на доц. Александър иколов Киколов: https:/www.uni-sofia.bg/index.php/bul/content/ download/150290/1085571/version/3/file/Spravka-AlexanderNikolov.pdf 
Qua data porta ruens, multisque in vincla petitis

Contendit magno ad Bizantia moenia bello

1389.

Hic ubi sexta illum pugnantem viderat aestas

Bella Sigismundus Gallis comitatus et Hunnis

Integrat. haud illi sese Thrax segnius offert,

Et qua Nicopolis surgit concurritur armis

Hinc atque hinc validis, oriturque miserrima caedes

Christiadum: lis causa mali, lis improba, primas

Dum sibi nunc Gallus, nunc arduus arrogat Hunnus. ${ }^{9}$

[II. A balkáni harcok, török-magyar-szerb-bolgár háborúk hullámzása Zsigmond idejében egészen Galambóc Zsigmond általi bevételéig, 1392-ig, illetve mindaddig, amíg Zsigmond át nem adja István szerb despotának a várat.]

Iam fratris dextra superis concessit ab oris

1401.

Moses, et Regem qui caeperat ante priorem,

1403.

Cum mites illi non longo tempore Turcae

Rursus in arma ruunt, Mahometi Thracia quando

1405.

Sceptra dat, is Dacos, et quae iuga ferre negabat

Bulgariam premit: huic Boio comitatus et Hunno,

Marte Sigismundus Caesar coit, hic ubi victor

Turca Columbacijs laetus se moenibus infert.

Atque hic exultans animis spolijsque superbis

Dura tributa ferox Daco imperat, Ioniosque

Contingit scopulos, primum rate traijcit Istrum. ${ }^{10}$

[III. Nándorfehérvár első, sikertelen török ostroma 1440-ben, valamint Hunyadi ez után következő nagy győzelmei a Balkánon, a hosszú hadjárat, majd az esküszegés miatt bekövetkező, Isten büntetéseként felfogott várnai vereség és I. Ulászló halála.]

9 CAMPANUS (1597: 5-6). Megjegyzendő, hogy mi a nyomtatványnak megfelelő sorok mellett tüntetjük fel a történeti dátumokat, azonban ezek igen nagy csúszással szerepelnek, mintegy húsz évvel előbbre hozva a valóságos eseményeket, legalábbis az első szultánok idejében. Így például az első rigómezei csatát, amely 1389-ben volt, tévesen 1377-re teszi a szerző. Konstantinápoly elfoglalásától, vagyis 1453-tól már helyesek a dátumok. Vö. BENDA (1983: 230-270).

10 CAMPANUS (1597: 6). 
Quatuor, hinc Venetis sua Thessalonica per illum 1438.

Demitur, et Bellogradum obsidione tenetur, (Bulgarus hoc castrum, cum iam diffideret armis Bulgariae, castris alijs pro pluribus unum Hungarico regi dedit, Hunnis rebus asylon Ut foret, et muris hostem seiungeret altis) Fulminat hic armis Thrax arduus, ardua contra Arx manet inconcussa, velut Marpesia cautes: Instant ardentes Hunni, nec saxa nec ullum Telorum interea cessat genus: avolat inde Rex Geticus belli sortem indignatus acerbam, Atque novas acies agit, illum bella minantem Hungariae, Hunniades contra se strenuus offert 1439. Inque Haemi campis superatum ad foedera cogit. 1440.

Non tulit hanc pacem praesul Romanus, et arma Arma Getis moveamus, ait, dicto ocius omnes Prosiluere Patris monitis parere parati.

Hic Thrax (ut perhibent) violati foederis ira Multa Deos orans oneraverat aethera votis.

Si Deus es Crucifixe, tuum qui fallere numen, Per quod iurarunt, audent, ait, hos age dignis Exerce poenis, liceat punire merentes, Foedifragumque istis liceat domuisse sub armis. Sic fatus: curvum vagina protinus ensem Eripiens volat, huic comes omnis Thracia pubes. Et qua Varna suas despectat lubrica lymphas. Ingentes coeunt acies, haud numine nostro, Rex etenim VVladislae cadis, cadit improbus osor Foederis, a magno demissum nomen Iulo Triste gemens (at tu dictis Romane maneres) Foedifragique viri peraratur acynace pectus. Hunniades, Thracum per mille sequentia tela Surripiens sese fugit ilicet ocior Euro, Et montana petit, pedibus timor addidit alas. Constitit haec Turcis etiam victoria magno, Nec tamen absistunt, cladem iuvat addere cladi, Et glomerare manum bello, et concurrere in hostem: 1446. Attilidae contra magna nituntur opum vi. Quis cladem illius pugnae, quis funera fando 
Explicet? hoc natum bello sibi luget ademptum

Turca, furensque quid hic omnes moriemur inulti?

Non moriemur, ait: nec multa moratus ovantem

Hunniadem flammaque Getis ferroque minantem

1448.

Accurrens fugat, et quinque atro millibus Orco

Immissis audere suos in praelia cernens

Cuncta ruit, Scopiam et Sophiam capit, oppida clarae

Bulgariae, generumque fugat, securus amorum

Coniugis: hinc pugnas atque invidiosa perosus

Sceptra subit claustrum, positisque inglorius armis

Exigit aetatem. Negat illi gaudia pacis

Filius, ante annos sceptrum, cumque hoste potenti

Bella gerens, rogat ille patrem succurrat egenis

Rebus, et effrenes compescat militis ausus.

Audivit senior, dumque aestuat ira, (lupus ceu

In densa raptor nebula, quam livida ventris

Exegit caecum rabies, catulique relicti)

Fertur in arma furens, et dudum impune rebelles

Ultus caede viros, validis citus imminet Hunnis,

Tum quoque Scanderbege premi obsidione videbas

Ematijs Troiam campis, ubi Thrax gravis aevo

Dira fremens, quod non obsessam vinceret urbem

Effugientem animam quassans caput exhalavit. ${ }^{11}$

[IV. A világraszóló nándorfehérvári diadal.]

Hic Mars Vulcanusque fremunt: unde horridus hostis

Asper acerba tuens Graiae, arduus imminet Albae:

1456.

Et dum lustrat equo passim loca, dumque minantes

In coelum muros tentans huc fertur et illuc,

Huniades [sic!] fulmen belli, fortissimus heros,

Illum, arci, casus supremaque fata minantem

Summovet Hungaria: vidisses fata Tyrannum

Lugentem sua nec quicquam studijsque furentem,

An sese mucrone ob tantum dedecus ultro

${ }^{11}$ CAMPANUS (1597: 7-9). Az esküszegés tematikájához vö. SZENTMÁRTONI SZABÓ (2012: 183-194). 
Induat, an medijs iaciat se fluctibus excors?

In Persasne omnes irarum effundat habenas? ${ }^{12}$

[V. A törökök Isza boszniai pasa vezetésével betörnek Horvátországba és Szlavóniába.]

Tum quoque bellaces invadit Thracius Hunnos

Ensis, ibi Getica tum millia dena trahuntur

Capta manu: quin Dalmaticis quoque finibus ampla

Praeda agitur, multi praestantes corpore Tauri. ${ }^{13}$

[VI. Mátyás király segítséget nyújt a török ellen Otrantónál; II. Mehmet halála; II. Bajazid trónra kerül; Szkander bég vitézsége; Mátyás megostromolja és elfoglalja Szabács várát. Persze olvashatunk Jajcáról és Mátyás más győzelmeiről is. A nagy királyt egyébként külön, sírfeliratnak is beillő sorokban búcsúztatja a költő, ahol nemcsak az ő saját diadalait sorakoztatja föl, hanem összekapcsolja személyiségét atyjának győzelmeivel, és leszögezi, hogy ha nem halt volna meg, a török későbbi győzelmei nem következtek volna be.]

Hinc Hunnum terra sed te petit Appule lympha: 1479.

Mittitur imperium in Scythicum nemorosa Zachynthos,

Leucadiaeque sinus et Neritus ardua saxis,

Et vicina mari Calabris in montibus Hydrus.

Processurus erat, non sivit Rector Olympi

Ille oras bellis gravidas miseratus et urbes,

Regnatorem Asiae magnum parva obruit urna

Vitaque cum gemitu fugit indignata sub umbras.

1482.

Quaeritur hic alius, nec quisquam ex agmine tanto

Baia

Baiazete prior, solo minor ille Parente

zetes 2

Arcet longe Asia fratrem: illis forte diebus

Turca

Hydruntem Alphonsus recipit, Castrottus aviti

Regna soli, satus Huniade Bosnensia regna rum Rex

His commotus atrox hostis Nilique Rhodique $9 \operatorname{Im} 2$

Pacem orat, voti compos Valacho imminet, atque 1483.

Victor sede Getas alibi deturbat avita, 1484. 1486.

12 CAMPANUS (1597: 9-10).

13 CAMPANUS (1597: 11). 
Ipsa etiam positu defensa Ceraunia dudum 1492.

Passa iugum Mahometigenum flent triste, tyrannus

Interea Cilicum condensis obrutus armis

Millibus exuitur ter denis: tum quoque Turcis

Sabbatium praestans animi Corvinus ademit,

Corvinus, quem Marte potens: dum vita manebat,

Hunniades terrorem inter Martisque labores

Erudijt Pater, et magnis adiunxerat ausis. ${ }^{14}$

[VII. Nagy Szulejmán diadalútja Nándorfehérvár elfoglalásától Mohácsig, Budáig, illetve Bécs ostromáig.]

Quis procul ille virum, facies cui fusca, comaeque

Tantum in fronte aliquae, macies in corpore toto,

Ardentes oculi suffecti sanguine et igni,

Ipse minax, gradiensque alios supereminet omnes

Agnosco. Solymannus hic est catus, arduus, audax:

Nec tamen indocilis pacis, prope limine in ipso

Imperij legatum audaces mittit ad Hunnos:

Quid malint referat pacemne, vel arma? det arma,

Conclamant illi. quae vobis tanta cupido

Istricolae, quae tanta venit fiducia? vestris

Cladibus irruitis, nocituraque poscitis arma.

Iamque (videtis enim) tot magnis clara triumphis

Inconcussa diu, Solymanni viribus ingens

Succumbit Graia Alba, ruit victricibus armis

Sabbacium, nec quae Mahometem infracta secundum

Reppulit, hunc etiam potuit superare furentem

Phaebo grata Rhodus, nec eum satis insula ${ }^{15}$ texit,

Sirmia claustra sua qui tum ditione tenebat.

Occidit Hungaricis etiam Ludovicus in armis

Ora puer prima signans intonsa iuventa:

Illum, quae bello dederat, lux invida secum

Abstulit, evulsus simul armiger omnis, et omnis

Hos iuvenum virtusque virum. Scytha deinde Viennam

Austriacam saeva ferus obsidione premebat:
Solyman

nus Tur carum rex

11. Im-

perat: 4 .
1521.

1522.

1525.

1526.

\footnotetext{
14 CAMPANUS (1597: 11-12).

15 A nyomtatott szövegben sajtóhibával így áll: „infula”.
} 
Et iam parte aliqua tormentis moenia rumpens

Urbi incumbebat, cum se Germanicus illi

Obtulit, inque fugam facto agmine vertit Achilles.

1529.16

[VIII. Pest és Esztergom elfoglalása; ez utóbbi 1543-ban történt. A törökök győzelméhez hozzájárult az a hadicsel, amelynek a várat védelmező Francesco Salamanca spanyol és Martino Lascano olasz vezér felült, és amely miatt később börtönbüntetést is szenvedtek.]

Hinc Pestum capiunt, deque altis turribus alti 1541.

Strigonij stultae Salamancae fraude triumphant. ${ }^{17}$

[IX. Temesvár eleste és Losonczy István sorsa; Szolnok vesztése; Eger sikertelen török ostroma; az első, szintén sikertelenül végződött kísérlet Szigetvár elfoglalására. Végül Schwendi győztes téli csatája Tokajnál.]

At Temeschuarum validis circumsonat armis, 1552.

Qui Budae praefectus erat: Losontius illum

Nec quicquam sese contra fert arcis et urbis

Et Ducis unus erat casus, tres una videbat

Atra dies nigra mergi caligine victos.

Et iam Zolnocco capto, super Agria bello

Prima fugit, Budensis eam quoque Marte fatigat

Bassa, sed incassum. nec sors est laeta tuorum,

Quos ad Segetum tuleras, Halibassa, laborum:

Ergo fugis repetisque tuas inglorius oras.

De hinc redeunt in amicitias et foedera iungunt

1560.

Bistinius Rex et Latius, multosque per annos

Christiadae placida laetati pace fuissent.

$\mathrm{Ni}$ furiae Eumenides in Martis Iazygas arma

Traxissent: illis se Schvendius impiger offert,

1564.

1565.

\footnotetext{
16 CAMPAnUS (1597: 14-15). A szövegrészben emlegetett „német Achilles” nem más, mint Salm Miklós (Niklas von Salm gróf), aki hetvenéves korában hősiesen visszaverte Szulejmán ostromát.

17 CAMPANUS (1597: 16).
} 
Et dum saevit hyems, glacie dum stringitur unda

Toccaio potitur, seque arci maximus infert. ${ }^{18}$

[X. Várpalota, Tata, Veszprém, végül Szigetvár és Gyula veszedelme. Az utóbbi vár kapitányaként feltüntetett Leresthenius természetesen sajtóhiba vagy rossz forrásra visszamenő névalak, mert Kerecsényi Lászlóról van szó, akit sokáig árulónak tartottak, és csak az utóbbi időben rehabilitálták a történészek, illetve az irodalomban Zalán Tibor drámája is. ${ }^{19}$ Szulejmán úgy suhan alá az alvilágba Szigetnél, mintha olvasta volna Vergiliust.]

... quo tempore rursus ad Hunnos

Mars redit, incumbens Palotae, quam extrema timentem,

Nutantemque suis comes Helfenssteinius armis

Liberat: inde Tatae, et vobis Vesprinia [sic!] castra

Subvenit. interea magna se mole movebat

Maximus Aemylius sociosque in bella vocabat:

Conveniunt quibus aut odium crudele tyranni

Aut metus acer erat: sed enim versutior hostis

Sigethum petit, hic telis, hic milite multo

Fulminat incursans, nunc hac, nun [sic!] fervidus illac.

Undique pugnatur, telorumque ingruit imber,

Quam multa in tectis crepitans salit horrida grando.

Nicoleos ubi iam Zerinius haud magis illos

Insultus suffere potest, media insilit arma

Procumbens, pulcramque petit per vulnera mortem,

Arx antiqua, potens armis, remora hostibus ingens

Thracas habet Dominos. Iulae quoque fata requiris?

Illa Leresthenio [sic!] frustra defensa, repente

*Selimus

Insueto dat colla iugo, cum Martius horror

2. Turca

*Indignantem animam reddit Solymannus averno.

rum rex 12

Imp: $5 .^{20}$

[XI. Zrínyi György tárnokmester vitézsége; Törökkoppány (Somogy megye) és Limbach (Vas megye, magyar nevén Hárspatak, jelenleg Bur-

\footnotetext{
18 CAMPANUS (1597: 16-17).

19 ZALÁN (2013: 76-102).

${ }^{20}$ CAMPANUS (1597: 17).
} 
genlandban) ostroma, ahol Zrínyi bajtársai Batthyány Boldizsár és Nádasdy Ferenc voltak.]

Nec minus Hungarica belli furit aestus in ora. 1586.

Ille Croatinis invadit Thracas in agris,

Diversosque ait. hic Bosnae qui sceptra tenebat

(Bistonide Bassam patrio cognomine dicunt)

Germanum gemit: unde ferus calida aestuat ira.

Hunni nil, nec eum volventem dira morantur.

Sed Copanum cingunt arcem, ruit illa, fenestram

1587.

Dans magnam, Turcae manibus post terga revinctis

Raptantur, neque praefectum volucris fuga servat.

Hinc magis atque magis dolor et pudor armat in Hunnum

Bistonas. Ergo citi ferro populantur et igne

Obvia, Limpaci qua limpida lympha susurrat.

Non impune tamen: nec enim Zerinius heros

Oblitus virtutis erat, laudisque paternae:

Ille ubi sera dies, statioque accomoda fraudi

Promittunt praedas, Scythicam, quae cuncta putabat:

Tuta, volans aciem turbat, versaeque phalanges

Reijciunt gladios, et nostris arma ministrant.

Hoc ubi magnanimus Zerinius agmine vidit

Accelerare fugam in sylvas et sidere nocti,

Persequitur multosque necat sub luce maligna. ${ }^{21}$

[XII. Sziszek (horvátul Sisak) híres ostroma, ahol a magyar parancsnok, Miskolczy Miklós (latinul Miccatius) megadást színlelve becsalta a boszniai basa teljes vezérkarát és ágyúkkal lemészároltatta őket a várudvaron. ${ }^{22}$ A szultán, mint tudjuk, a kortársak szerint ezen háborodott fel annyira, hogy felbontotta a békét, és hadat üzent a német-római császárnak, így kezdődött tehát a magyar hadtörténetben tizenöt éves háborúnak, máshol a Habsburgok hosszú török háborújának hívott korszak. A szövegben szereplő Thressina valószínúleg azonos a görög Théraszia nevű kis szigettel, amely Krétától északra található. Követke-

${ }^{21}$ CAMPANUS (1597: 20).

22 Vö. BARANYAI DECSI (1982). 
zik Veszprém, majd Palota elfoglalása, azután Fülek ostroma; Szinán basa gyalázása.]

Tum quoque Styriacas qua semita ducit ad urbes

1593.

Siseccum petitur: sed ibi Miccatius hostem

Fortior elidit dux impiger, huc tamen illis

Non remeare metus. quae tanta amentia vobis

Lunicolae? belli quae tanta cupido fatigat?

Victa ne dat fastus Thressina? quid? hoc quoque demens

Sperasti te Turca dolo subvertere castrum?

Non facies: haud ille sinit Regnator Olympi.

Quin morere, et gelidis Siseccum quaere sub undis

Impastique aderunt qui lambant vulnera pisces,

Haec te digna manent pro tantis praemia factis:

Plura ferent socij: nam quos in gurgite vasto

Non volvent undae, palo Hunnus figet acuto,

Crudeles alijs arcebunt vincula palmas.

Audit Amurrates fatum ducis, ilicet ergo,

Ut primum furijs stimulantibus arsit anhelus

Corde dolor, quassans caput, et iam pacis amicae

Impatiens, bellum bellum te poscimus, inquit.

Atque illum tales agitantem pectore curas

Bassa Sinan acuit, quo non crudelior alter

Christiadum flamma ferroque excindere fines.

Accedunt lachrymae matris (soror illa Tyranni

Thracis erat) rapti lugentis funera gnati.

Illius hic casu evictus vincla omnia rumpit,

Ad bellumque vocat Latio cum rege gerendum.

Iamque (quid invitis fac quenquam fidere divis?)

Sisecco potitur: studijs asperrima belli

Pectora Tevtonidum captam despensa per arcem

Thrax in frustra secat, Colapique trementia mergit.

Tum vobis etiam Vesprinia [sic!] castra superba

Virtute exultans, illabitur: hic ubi creber

Arietat in muros et duros obice postes.

Limen erat, caecaeque fores: et pervius arcis

Usus, ea nostri furtim, quando ultima cernunt,

Tuta petunt, subolens id Thracis odora canis vis

Arce sub imperium missa, fugientibus instat, 
Iamque hos, iamque illos crudeli funere mactat:

Et te faedifragis necquicquam credula Mauris,

Palata [sic!], Poena fides malefidi perdidit hostis

Poena tamen Poenum manet. illum respice, contra

Qui se parte movet nostra fortissimus heros

Tiefembachius, ut contra ruat impiger, illi

Ut se submittant Fileccia moenia, quaeve

Praeterea numeris non est comprendere nostris.

Accipe nunc Thracum insidias, et crimine ab uno

Disce omnes. ubi victa rapi Fileccia vidit

Castra Sinan, haesit primum, mox fraude subintrans

Hungariam, precio Iaurinas occupat arces.

1595.

Quid facis? arma manu potius, celeresque sagittas

Corripe, parce auro: tenuis nam gloria, si quis

Arces non adimat sed emat: num talibus olim

Fraudibus Albani Patres, quibus esse satum te,

Mentiris, populos magna ditione premebant?

Non venit in mentem folijs mandata per aevum

Vivere facta Ducum: de te quoque fraude vel armis

Viceris, inquirent alij, reprobusque fereris.

Quid loquor? aut ubi sum? quae fundo minantia frustra

Non mea dicta Sinan placidam demittit in aurem.

Fallere prima Getis laus est, et vivere rapto:

At fraudes nescire nefas vel morte piandum. ${ }^{23}$

[XIII. Rudolf császár dicsőítése, akinek személye garantálja a nemsokára eljövendő biztos és teljes győzelmet a török felett; majd elérkezünk 1596-hoz, ahol is a hős Mansfeld vissza tudta foglalni Esztergomot. Ez a győzelem a város múltbeli jelentőségénél fogva mintegy garantálja a nemsokára elkövetkező végső keresztény győzelmet, amely - és itt a szerző megint átmegy kissé ókori rómaiba - nemcsak azt jósolja, hogy az egész török társulatot le fogja törölni a föld színéről a német-római császár, hanem azt is, hogy eljut oda, ahová minden nyugati császár vágyakozott Nagy Sándor nyomán, vagyis egészen Líbiáig és Indiáig. Úgy látszik, a derék Vergilius-olvasó Campanus jós is volt, aki nemcsak a zsitvatoroki békét látta előre, hanem az arab tavaszt is... Mindenesetre a

${ }^{23}$ CAMPANUS (1597: 21-23). 
végén udvariasan leszúrja saját magát, mintha ő lenne Szinán basa, mert versei természetesen méltatlanok ahhoz a nagy feladathoz, amelyek majd Ausztria nagy győzelmét fogják zengeni. „Ez a harc lesz a végső!"]

At tibi contortos coram qui cernere fratres

Ausus es, ille DEUS summi Regnator Olympi

Praemia digna dabit, neque fallax dicar aruspex.

Ille (vides?) dubium, maior pietate, vel armis

Caesareus sanguis, sed Caesar et ipse, Rodolphus

Ut tibi Teutonicis alis Latijsque minetur

1596.

Auxilijs superum? viden hoc mandante moveri

Divitis Europae late loca? quid? nihil urgent

Bella Sigismundi te principis? et nihil, ipsum

Quae sequitur, Metanastarum manus inclyta bello

Ille adeo qui Strigonia te dividit arce

Dux praestans animi, sanguis Mansfeldicus, hosti

Quae tibi damna daret, nisi tam laudata professum

Ostendant Hunnis tantum fera fata, nec ultra

Esse sinant? memoremne alios, quibus ordine longo

Et rapere et raptas Latio iuvat addere regno

Strigonias turres veterum munimen avorum?

Aspice Vissegradum, praedatricesque superbi

Hattvani victas acies, victosque penates:

Nec quae causa necis multis fuit, Agria reddat

Te tua securum: sunt nobis fortia bello

Corpora adhuc, sunt et vires, sunt et sua nostris

Castra, nec illa tuis perierunt cuncta rapinis,

Credo equidem (caeptis faveat modo Numen amicum)

Consilia in melius referent et Pannones, et qui

Iam dudum Hungaricis avertunt finibus hostem

Belidae duri, genus insuperabile bello.

O mihi tam longae maneat pars ultima vitae

Cum nostri proceres ultra et Garamantas et Indos

Te pulso, spolijs redeant orientis onusti.

Tum mea, deductos tibi [*quae] sine pondere versus

Musa strepens vomit, atque incondita carmina frustra

Vociferans studio iam dudum iactat inani,

In melius numeros referet, magnosque sonabit 
Austriadas meliore sono. O illam optime rerum

Iova diem laetis mihi da fulgere quadrigis.

\section{FINIS. ${ }^{24}$}

A kötet második fele (Altera Otomannicorum principum descriptio in qua ipsi res a se gestas kai ta [sic!] prosopopoeiam [sic!] recensent) tartalmazza Oszmántól kezdve az írás jelenében uralkodó III. Mehmetig a török uralkodókat, ahol külön-külön feltünteti azt, hogy mettől kezdve viselhették a szultáni, illetve császári címet. Itt ezen főszereplők maguk mondják el önjellemzésüket, mintegy ön-sírfelirat - vagy mint a cím egy-két sajtóhibával görögül jelzi, prosopopoeia - formájában. ${ }^{25}$ Érdemes idézni egy pár sort II. Mehmet önéletrajzából, mert hiszen őt verte el Belgrád alól Hunyadi, illetve a számunkra oly végzetes Nagy Szulejmán curriculumának egész szövegét.

MAHOMETES II. REX TURcarum VIII. Imperat: I.

$[\ldots]$

Visa invicta diu Bisantia moenia caepi,

Moenia semper avis invidiosa meis.

$\mathrm{Nec}$ mora, dum regni caput a cervice revulsum est,

Imperium subeunt Dalmata Phryxque meum.

Progredior, magna iuvenum stipante caterva,

Graecaque militibus cingitur ALBA meis.

Efficit Hunniades mihi patrius hostis, ut inde

Pene quater denis millibus orbus eam. ${ }^{26}$

\section{SOLYMANNUS TURCARUM}

Rex XI. Imperat: IIII.

Nec mihi praefer avum Solymanno, nec mihi Patrem

Nec proavos: proavis maior avisque fui.

Hinc tot avis atavisque meis invicta, repente

Graeca meo sese subdidit ALBA iugo.

\footnotetext{
${ }^{24}$ CAMPANUS (1597: 23-25).

${ }^{25}$ Erről a retorikai ihletésü irodalmi müfajról és rokonairól vö. BÁNHEGYI (1943).

${ }^{26}$ CAMPANUS (1597: 32).
} 
Postque tot eventus, et iniquis concita Divis

Proelia, Carpathio marmore tuta Rhodus.

Tu quoque bella puer mihi necquicquam irrita misces

Heu confise Hunnis Rex LUDOVICE tuis.

Victus ubi es? tu deinde meis ingentibus armis

Disce puellae tuas abstinuisse manus.

Vix abij, cum Sepusius sibi regna Ioannes

Hunna petens, illuc meque meosque vocat.

Impetrat, et regnat: mihi ianua laxa volanti est,

Ergo Getis muros cingo Vienna tuos.

Tunc assueta meis dudum victoria castris

Cultoremque suum, notaque signa fugit.

Quid facerem? feror ad Persas, huc arma moventem

Cycladas Aegeas obstupuisse ferunt.

Rex, neque me Arsacidum, laetatus es hospite, Thoma

Nam dederas regnis oppida multa meis.

Quae premit Euphrates cum Tygride regna, tuosque

Assyrios nostrum mittis in Imperium.

Forte obit, Hungariae dedimus cui sceptra, meamque

Et puer et Coniux regia poscit opem.

His ego, dudum inhians Budae, ne poscite, dixi

Hungariam: puerum non feret illa Ducem:

Vos Transylvanis melius regnabitis oris,

Hic est praesidio Buda tuenda meo.

Quid faciant? cedunt, seque in meliora reservant:

Budaque sub nostro milite pressa gemit.

Huic comes it Granum, nec iam vim sustinet Alba

Regalis, nostrum fertque subacta iugum.

Tu quoque de septem quae totum respicis orbem

Collibus, es Regno Roma petita meo.

Te mihi deberi furiata mente tonabam,

Qui Constantini Regia sceptra feram.

Tum quoque cum cecidi, quam millia multa cecidi.

Experta est vires ar ${ }^{27}$ Segetina meas.

Sed pugnas si quis nostras desiderat omnes,

Plus prope quam fieri res sinit, ille petit,

Hercule neglecto, mea scribite bella Poëtae:

27 Értelemszerúen javítva, mert a nyomtatott szövegben ars áll. 
Hercule nam magno plura trophea tuli.

Adde quod illius pars maxima ficta laborum est:

Venit in annales fabula nulla meos.

Sed qui perdoumi Persas, Hunnosque Rhodumque,

Unam non potui perdomuisse necem..$^{28}$

Az egyes szultánok szájába adott önjellemzések igen izgalmasak. I. Bajazid például világosan és cinikusan kifejti, hogy a muzulmánoknak, illetve a törököknek a legnagyobb szívességet akkor teszik a keresztények, amikor egymás között veszekednek, így lesz lassan az egész világ török hódoltság. Ez már Magyarországon bebizonyosodott, és igaz ez Boszniára is. Nagy Szulejmán viszont kifejti, hogy legfőbb vágya akkor teljesült, amikor bosszút állt elődje, Mohamed csúfos futásáért Nándorfehérvár elfoglalásakor; II. Lajost éretlen kölyöknek tartja, aki jobb lett volna, ha nőkkel sem foglalkozik, nemhogy csatába merészeljen ereszkedni, a csecsemő János Zsigmondot és mamáját pedig atyai szigorral kergeti Erdélybe. Az alvilágból beszél a költemény fikciója szerint, mint valamennyi szultán, de legalább neki az a vigasztalása lehet, hogy meghalt ugyan Sziget alatt, de magával rántotta a pusztulásba a várat, sok törököt és Zrínyit is.

Emleget természetesen a költő horvát, szlovén, lengyel-kozák és cseh hősöket is e törökellenes áttekintésben, de ezek is teljességgel azonosulnak a magyar királyok és kapitányok által kitüzött és megvalósított célokkal, és osztoznak kudarcaikban. Ez utóbbit példázza, a moldvai-lengyel-kozák hetman, a török követelésére, a lengyelek által 1578ban kivégzett Jan Podkowa (ma emlékműve áll Lembergben), győztes katonaként pedig az a cseh Trczka gróf, aki a kassai főkapitány alatt részt vett 1594-ben Hatvan török helyőrségének elüzésében és a város lerombolásában. ${ }^{29}$

Milyen remény élhetett akkor 1597-ben a 15 éves háború kellős közepén?! A dolgok végkimenetele teljességgel bizonytalannak látszott. A háborút kezdő III. Murád már halott, és már csak a pokolban tud dicsekedni azzal, hogy nevetségesnek tartja, ha ôt ellenfelei, mint például

${ }^{28}$ CAMPANUS (1597: 35-37).

${ }^{29}$ CAMPANUS $(1597: 33 ; 39)$. 
Rudolf császár, zsarnoknak nevezik, mivelhogy nagyon jól tudja, hogy az volt, de erre büszke. Az élő szultán, III. Mohamed pedig boldogan tapasztalja, hogy a keresztény nemzetek viszálykodnak egymással, úgyhogy övé lesz a teljes Duna-völgy.

III. Mohamed reálpolitikus volt. Akárcsak II. Mohamed, aki a költeményben azzal dicsekszik, hogy szerencsére nem hisz semmilyen istenben, viszont a velenceiektől szép pénzen bérbe vette Gentile Bellinit, hogy fessen róla méltó arcképet.

(Annak idején már II. Piusz pápa is panaszkodott a bíborosok előtt, hogy a törökellenes hadjáratra összegyüjtött pénzének egy részét a francia király ellopta, és hadat indított a keresztény szicíliaiak ellen.)

Gömöri György egy tanulmányából ismerkedhetünk meg egy jóformán elfelejtett derék német-cseh Hungarusszal, ahogyan az Angliában élő irodalomtörténész nevezte, vagyis a selmeci Petrus Fradeliusszal. ${ }^{30} \mathrm{~A}$ költőként, matematikusként, gazdag úrfiak oktatójaként és elsősorban botanikusként jeleskedő Hungarust egyszer egy gyönyörü versben köszöntötte a mi Campanusunk. Ez nem egyéb, mint egy 1618-ban kiadott könyvecske elé írt ajánló vers, természetesen latinul. Fradelius akkor ugyanis kinyomtatott egy összesen négy leveles nyomtatványt, amelyből csak egy példány maradt fenn, és amelynek elején az ő régi barátja, a prágai professzorként akkor is jeleskedő Campanus mint a Magyar Királyság magasztalója tünik fel. Nem kevesebbet állít ugyanis, mint hogy legalább annyit utazott és kutatott a nagyvilágban a selmeci magyar, azaz Hungarus tudós, mint annak idején Ithaka ura, Odüsszeusz. Azonban neki volt hova hazatérnie, szegény Fradelius viszont azért bolyong folyamatosan, mert hazáját a gaz török nagyobbrészt elfoglalta és elpusztította. Ezt a ritka könyvecskét a cseh neolatin kutatások atyamestere, Jan Martínek találta meg és közölte egy latin nyelvü tanulmányában.

Ad auctoris patronos

Dux Ithac(us), plures populos qui viderat, optat fumum de patriis posse videre focis.

30 GÖMÖRI (2013/1: 95-98). 
Tanta virum patriae stimulabat cura videndae, ipso quae sterilis iudice et aspra fuit,

Omnibus ut talem regnis praeponeret unam atque urbes reliquas crederet esse nihil.

Fradelius, gentes varias qui vidit et urbes et meruit magnis posse placere viris,

Hungariam patriam, qua vix fecundior ulla est, non elegis gratus praedicet, ornet, amet?

Sed tamen illius non fumos optat et ignes, quos male sub duris viderat illa Getis:

Lumina pro fumo patriae pulcerrima cernens imparibus vates tollit ad astra sonis.

Quid precer huic animo? Placeat, celebretur, ametur, tam bene qui patriae lumina clara canit. ${ }^{31}$

Úgy gondolom, ez a vers is tanúsítja, hogy Campanus nemcsak olvasmányai alapján követte a török-magyar háborúk régmúltját és jelenét, hanem támaszkodhatott nagyon sok Prágában tanuló magyar diák vagy vele együtt a prágai egyetemen tanító Hungarus származású professzor baráti beszámolóira is. ${ }^{32}$

\section{Felhasznált irodalom}

BÁNHEGYI 1943 Kinnamos ethopoiája (Magyar-görög tanulmányok 23.), kiad. és magyarázta BÁNHEGYI György, Budapest, 1943.

BARANYAI DECSI 1982 BARANYAI DECSI János Magyar históriája (1592-1598), fordította és bev. Kulcsár P., Budapest, 1982.

BARlay 1977 BARlay Ö. Sz., Elias Corvinus és magyarországi barátai, Magyar Könyvszemle, 90/4 (1977), 345-353.

\footnotetext{
${ }^{31}$ MARTíNEK (1990: 52-56), a vers szövegét ld. az 52-53. lapon. Ezenkívül elérhető az interneten is: https://www.jstor.org/stable/23465497. Magyarország termékenységének toposzáról vö. IMRE (2003: 159-178).

${ }^{2}$ Végül: a cseh humanistáknak a magyar történelem iránti érdeklődésére, sőt szűkebben a magyar-török harcok iránti tanúsított figyelmére szeretnék itt emlékeztetni egy régebben kiadott szöveg említésével; ez nem egyéb, mint egy csehországi születésü, majd hosszú ideig Németországban és Olaszországban tanuló, végül Ausztriában letelepedő humanistának, Elias Corvinusnak (1537-1602) Hunyadi Jánosról írott eposza, ld. CORVINUS (1937). A szerzőről vö. Enchiridion (1966: 463-464), továbbá BARLAY (1977: 345-353); LÁNG-TÓTH G. (2009: 107-108); KISS (2017: 279-284).
} 
BENDA 1983

CAMPANUS 1597

CORVINUS 1937

Enchiridion 1966

GÖMÖRI 2013

GUTHMÜLLER-KÜHLMANN 2000

B. GUTHMÜLLER - W. KÜHLMANN (Hrsg.), Europa und die Türken in der Renaissance, Tübingen, 2000.

HEMELIK 2012

IMRE 2003

JANKOVICS 2000

KISS 2017

KLANICZAY 1991

MARTÍNEK 1990

PAPP 2018

Magyarország történeti kronológiája, A kezdetektól 1970-ig, Négy kötetben, I., A kezdetektól 1526-ig, BENDA K. (főszerk.), Budapest, 1983, 230-270.

Turcicorum tyrannorum qui inde usque ab Otomanno rebus Turcicis praefuerint descriptio a M. Iohanne CAMPANO Ec. Ubi res ipsorum gestae, historico ordine, additis in altera ubique annis, breviter exponuntur, Pragae, Typis Otthmarianis, Anno Domini 1597

Elias CORVINUS, Ioannis Hunniadae res bellicae contra Turcas. Carmen epicum (BSMRAe: Saeculum XVI), ed. Oscarius Sárkány, Lipsiae, B. G. Teubner, 1937.

Enchiridion renatae poesis Latinae in Bohemia et Moravia cultae Rukovět’ humanistického básnictví v Čechách a na Moravě, I, A-C, Opus ab Antonio TRUHLÁř et Carolo HRDINA inchoatum, Josef HEJNIC et Jan MARTíneK continuaverunt, Pragae, Academia, 1966.

GÖMÖRI Gy., Egy német-cseh Hungarus Londonban, Magyar Könyvszemle, 129/4 (2013) 95-98.

M. HEMELIK, Jan Campanus Vodňanský, Portrét renesančního básníka (Iglavia docta, 3), Jihlava, 2012.

IMRE M., A termékeny Magyarország toposza Szönyi Benjámin latin nyelvü versében, Könyv és Könyvtár, 25 (2003), 159-178.

J. JANKOVICS, The Image of the Turks in Hungarian Renaissance Literature, in: B. Guthmüller - W. Kühlmann (Hrsg.), Europa und die Türken in der Renaissance, Tübingen, 2000, 267-274.

KISS F. G., Elias Corvinus verse Radéczy püspök hárfájáról, in: Bajáki R. (szerk.), Lelkiség és irodalom: Tanulmányok Szelestei N. László tiszteletére, Budapest, 2017, 279-284.

A Bibliotheca Zriniana története és állománya / History and Stock of the Bibliotheca Zriniana (Zrínyi-könyvtár IV.), írták és összeállították HAuSNer G., KlANicZAy T., KOVÁCS S. I., MONOK I., ORLOVSZKY G., szerk. KLANICZAY T., Budapest, 1991.

LÁNG-TóTH G. 2009 LÁNG B. - TóTH G. P. (szerk.): A kincskeresés 400 éve Magyarországon: Kézikönyvek és olvasóik, Budapest, 2009.

LAUREYs 2010 M. LAUREYS, History and Poetry in Philippus Meyerus's Humanist Latin Portraits of the Prophet Mohammed and the Ottoman Rulers (1594). in: Y. Haskell, J. Feros Ruys (eds.), Latinity and Alterity in the Early Modern Period, Tempe, 2010, 273-299.

J. MARTíNEK, De Magistro Campano regni Hungarici laudatore, Listy filologicke / Folia philologica, 113/1 (1990), 52-56.

PAPP I, Biblikus cseh nyelvü gyászbeszédek a 17. századi Magyarországon, Budapest, 2018.

SZENTMÁRTONI SZABÓ 2012

SZENTMÁRTONI SZABÓ G., "Romulidae Cannas”, avagy egy ál-Janus Pannonius-vers utólete, eredeti szövege és valódi szerzője. in: Békés 
„SZERÉMI” 1877

VARGA 2016

WAGNER 1877

WIEGAND 2000

ZALÁN 2013
E., Tegyey I. (szerk.), Convivia Pajorin Klára 70. születésnapjára, Budapest-Debrecen, 2012, 183-194.

„SZERÉMI” [= herceg ODESCALCHI Arthur], Adalék a »Zínyiek Csehországban « czímü közleményhez, Századok, 11 (1877), 451-453.

VARGA Sz., Leónidasz a végvidéken, Zrínyi Miklós (1580-1566) (Sziluett, Korszerü történelmi életrajzok), Pécs-Budapest, 2016.

WAGNER T., A Zrínyiek Csehországban, Századok, 11 (1877) 162166.

H. WIEGAND, Neulateinische Türkenkriegsepik des deutschen Kulturraums im Reformationsjahrhundert, in: B. Guthmüller - W. Kühlmann (Hrsg.), Europa und die Türken in der Renaissance, Tübingen, 2000, 177-192.

ZALÁN T., A fáklya kialszik: történelmi dráma, Bárka, 21/5 (2013), 76102. 